\section{Pollinator-attracting Companion Plantings Increase Crop Yield of Cucumbers and Habanero Peppers}

John E. Montoya, Jr.

Department of Wildlife, Sustainability, and Ecosystem Sciences, Tarleton State University, Box T-0050, Stephenville, TX 76402

\author{
Michael A. Arnold \\ Department of Horticultural Sciences, Texas A\&M University, TAMU 2133, \\ College Station, TX 77843-2133
}

Juliana Rangel

Department of Entomology, Texas A\&M University, TAMU 2475, College Station, TX 77843-2475

\section{Larry R. Stein}

Department of Horticultural Sciences, Texas A\&M University, TAMU 2133, College Station, TX 77843-2133

\author{
Marco A. Palma \\ Department of Agricultural Economics, Texas A\&M University, 2175 \\ TAMU, College Station, TX 77843
}

Additional index words. Apis mellifera, Borago officinalis, Capsicum chinense, Cucumis sativus, Ocimum basilicum, Phyla nodiflora

\begin{abstract}
Cucumber (Cucumis sativus L.) and habanero pepper (Capsicum chinense Jacq.) growers have observed increased crop yield by placing bees in close proximity to these vegetable crops. However, adding managed bees typically may not be feasible for small-scale farmers or homeowners. Limited studies have demonstrated the potential of pollinator-attracting plants to be used as a lure to enhance the visitation of pollinators to adjacent food crops. This study evaluated the potential of adding pollinator-attracting plants in close proximity to cucumber and habanero plants to improve yields by either establishing permanent perennial companion plantings adjacent to the crops or interplanting annual companion plants within the row anew with each crop. The perennial treatment group consisted of Phyla nodiflora (L.) Greene, Borrichia frutescens (L.) DC., Salvia farinacea Benth. 'Henry Duelberg', and Eysenhardtia texana Scheele. The annual treatment group consisted of Cosmos bipinnatus Cav., Zinnia $\times$ marylandica D.M. Spooner, Stimart, \& T. Boyle, Borago officinalis L., and Ocimum basilicum L. Multiple cropping cycles were initiated using both spring and fall seasons, and yield was assessed for three successive cropping cycles. Fruit quality was unaffected by pollinatorattracting companion plantings; however total and marketable yields were impacted. Cucumber yields were significantly $(P<0.05)$ greater during fall harvests with annual companion plantings and with the second fall harvest in perennial companion plant plots. Perennial companion plots initially yielded less than control plots or annual companion plots due to the space allocated to the companion plantings and the fewer pollinators initially attracted to the plots compared with the annual companion plantings. When the perennial plots became more established, they resulted in similar yields as the annual companion planting plots. Although habanero yields were increased by annual companion plantings in spring and fall, cucumbers were unaffected by companion plantings in spring. This suggests a potential seasonality for the efficacy of some pollinator-attracting companion plantings for a given crop that could offer an opportunity to tailor companion plantings to attract specific pollinators at different times of the year.
\end{abstract}

Decreasing honeybee (Apis mellifera L.) populations are becoming a nationwide concern with numerous consequences, including inadequate pollination of several crop species (Calderone, 2012; Gallai et al., 2009; Kevan and Phillips, 2001). Therefore, it is important to investigate crop production systems that incorporate companion plantings that attract honeybees and other pollinators to agricul- populations of pollinators around those crops.

Even though the addition of companion plantings to crops has been known to increase insect diversity, further research is needed to determine if crop yield can also be reliably increased in those systems (Haaland et al., 2011). Similarly, to support more abundant and diverse pollinator populations and simultaneously improve crop yields, research has suggested that the planting of floral restoration plant varieties to attract pollinators and help "export" them to adjacent crop fields can be effective (Morandin and Kremen, 2013). However, the selection of proper companion plants that flower in synchrony with a particular crop and meet the requirements of the particular growing conditions of the region needs to be investigated more extensively to maximize pollination and crop yield (Quinn et al., 2017).

Across heterogeneous landscapes, pollinator abundance and pollinator diversity typically correlate with floral diversity and density (Potts et al., 2003). Julier and Roulston (2009) found that, provided a farm was not located in an intensively farmed region, wild pollinators alone were sufficient to pollinate pumpkin (Cucurbita pepo L.) crops. Therefore, the following question arose: would adding pollinator-attracting plant species, thereby transforming a given area into a more heterogeneous landscape, attract sufficient pollinators to successfully pollinate a crop without the addition of managed honeybee hives? Previous studies have investigated similar questions, but none has directly quantified differences in yield. Barbir et al. (2015) tested multiple herbaceous plants, including borage (Borago officinalis), to find suitable plant species in Spain with the ability to attract pollinators in agro-ecosystems. Carreck and Williams (2002) found that the addition of annual flowering plants (including $B$. officinalis) to noncropped areas of field production provided nectar and pollen sources to pollinators, even during the offseason. Thom et al. (2016) found that the addition of oilseed crops, including borage, to soybean [Glycine max (L.) Merr.] and maize (Zea mays L.) crops provided a supplemental nectar resource for pollinators and a highvalue crop for farmers.

Frogfruit (Phyla nodiflora), an herbaceous perennial groundcover, is widely known regionally as a pollinator-attracting plant (Redhage and McDermott, 2015). Salvia farinacea 'Henry Duelberg' is a reliable herbaceous perennial sage originating in Texas that is known for its butterfly-attracting seasonlong blooms (Texas Superstar Program, 2016). Sea oxeye (Borrichia frutescens) is tolerant of periodic flooding and salty high $\mathrm{pH}$ soils; it is a small evergreen to semi-evergreen shrub native to the southern U.S. coastal regions that attracts pollinators (Gilman, 1999). Kidneywood (Eysenhardtia texana) is a small deciduous shrub that is native to Texas and is known for its recurrent flushes of pollinatorattracting flowers (Arnold, 2008). In addition to borage (B. officinalis), which was 
previously discussed, annual pollinatorattracting plants with small to medium statures reported to attract pollinators and grow well in gardens of the region include cosmos (Cosmos bipinnatus), zinnias (Zinnia $\times$ marylandica), and basil (Ocimum basilicum) (Arnold, 2008).

Cucumber is highly dependent on pollinators for fruit set (University of Georgia Honey Bee Program, 2019). Increased visitation of pollinators has been shown to increase fruit set of $C$. chinense (Cauich et al., 2006). Several cultivars of cucumbers are commercially grown in Texas (Masabni, 2010). Cucumbers and peppers are among the more popular vegetables for residential gardeners in Texas (Cotner, 1998). Texas ranks third in national production of hot peppers (Food and Drug Administration, 2016). The objective of this study was to evaluate the impact of pollinator-attracting perennial plants compared with both pollinator-attracting annual plants and plots lacking pollinator-attracting plants (control plots) on cucumber (Cucumis sativus) and habanero (Capsicum chinense) crop yields and fruit quality.

\section{Materials and Methods}

The greenhouse production portion of this experiment was conducted at the Texas A\&M University Horticultural Teaching, Education, and Research Center (HortTREC) in College Station, TX (lat. $30.52^{\circ} \mathrm{N}$, long. $96.43^{\circ} \mathrm{W}$ ) in Fall 2016, Spring 2017, and Fall 2017. Greenhouses were equipped with automated shade cloths that closed to provide $44 \%$ light exclusion when light sensors exceeded $750 \mu \mathrm{mol}$. Minimum and maximum temperatures during the experiments were recorded (Table 1).

\section{Annual plant species}

Annual companion plant species were selected with preference given to annuals that are well-known pollinator attractors that grow well in Texas (Arnold, 2008). The four annual pollinator-attracting companion plant species selected were Borago officinalis, Cosmos bipinnatus, Ocimum basilicum, and

Received for publication 7 Aug. 2019. Accepted for publication 7 Aug. 2019.

Published online 10 January 2020.

This study was included as part of a dissertation written in partial fulfillment of the requirements for the $\mathrm{PhD}$ degree by John E. Montoya. This work was supported in part by funds from Texas A\&M AgriLife Research through National Institute of Food and Agriculture appropriations. Mention of a trademark, proprietary product, or vendor does not constitute a guarantee or warranty of the product by the authors, Texas A\&M University, or Texas A\&M AgriLife Research and does not imply its approval to the exclusion of other products or vendors that also may be suitable.

J.E.M. is the corresponding author. E-mail: montoyaj@ tamu.edu.

This is an open access article distributed under the CC BY-NC-ND license (https://creativecommons.org/ licenses/by-nc-nd/4.0/).
Zinnia $\times$ marylandica. The plants were germinated from seed in greenhouses during Fall 2016, Summer 2017, and Fall 2017. Annual seeds were hand-planted in 0.16 -L cells $(606$ cell flats; T.O. Plastics, Clearwater, MN) filled with Metro-Mix 700 media (Sun Gro Horticulture Canada Ltd., Vancouver, BC) and hand-watered as needed. Liquid fertilization (300 mg. $\mathrm{L}^{-1}$ of $\mathrm{N}$ from Peters Professional 20N-8.74P-16.6K; Scotts Co., Marysville, $\mathrm{OH})$ was provided on a weekly basis.

\section{Perennial plant species}

Perennial companion plantings were established in rows adjacent to where vegetable crops were grown. The four regionally well-adapted perennial pollinator-attracting companion plant species used were Phyla nodiflora, Borrichia frutescens, Salvia farinacea 'Henry Duelberg', and Eysenhardtia texana (Arnold, 2008; Gilman, 1999; Redhage and McDermott, 2015; Texas Superstar Program, 2016). The plants were propagated clonally from stock plants maintained in a gravel-bottom nursery in College Station, TX (lat. $30^{\circ} 37^{\prime} 24.24^{\prime \prime} \mathrm{N}$, long. $-97^{\circ} 22^{\prime} 0.17^{\prime \prime} \mathrm{W}$ ) in Feb. 2016. Eysenhardtia texana plants were purchased in no. 2 containers $(6.3 \mathrm{~L})$ from Barton Creek Nursery, Austin, TX, and planted directly in the field on 15 Mar. 2016.

Borrichia frutescens and Phyla nodiflora were propagated by tip cuttings 4 to $6 \mathrm{~cm}$ long, with basal ends of cuttings dipped in talc-based indole-3-butyric acid at a concentration of $1 \mathrm{~g} \cdot \mathrm{kg}^{-1}$ (Hormodin ${ }^{\circledR} 1$; OHP, Inc., Mainland, PA). Cuttings were placed in 36$\mathrm{cm} \times 51-\mathrm{cm} \times 10$-cm deep flats (Kadon Corp., Dayton, $\mathrm{OH}$ ) filled with coarse perlite (Sun Gro Horticulture Canada Ltd., Vancouver, BC). Intermittent mist was applied at 16-min intervals of $15 \mathrm{~s}$ each using collected rain water set to a light sensor programmed to operate at sunrise and sunset. Rooted cuttings were potted in $0.47-\mathrm{L}$ black plastic pots (Dillen Products, Middlefield, $\mathrm{OH}$ ) containing Metro-Mix 700 media and hand-watered. Fertigation $\left(300 \mathrm{mg} \cdot \mathrm{L}^{-1}\right.$ of N Peters Professional $20 \mathrm{~N}-8.74 \mathrm{P}-16.6 \mathrm{~K})$ was applied on a weekly basis.

Salvia farinacea 'Henry Duelberg' was propagated by stem cuttings and potted in 2.5-L black injection-molded pots (Dillen Products, Middlefield, $\mathrm{OH}$ ) containing MetroMix 700 media and hand-watered. Plants were fertigated $\left(300 \mathrm{mg} \cdot \mathrm{L}^{-1}\right.$ of $\mathrm{N}$, Peters Professional $20 \mathrm{~N}-8.74 \mathrm{P}-16.6 \mathrm{~K}$ ) on a weekly basis.

\section{Vegetable crop species}

Cucumber (Cucumis sativus 'Marketmore') was propagated in greenhouses at the HortTREC on 28 July 2016, 7 Mar. 2017, and 1 Aug. 2017. Plants were hand-seeded in 0.16-L cells (606 cell flats; T.O. Plastics., Clearwater, MN) filled with Metro-Mix 700 media and hand-watered as needed. Plants were fertigated $\left(300 \mathrm{mg} \cdot \mathrm{L}^{-1}\right.$ of $\mathrm{N}$, Peters Professional $20 \mathrm{~N}-8.74 \mathrm{P}-16.6 \mathrm{~K}$ ) on a weekly basis.

Habanero pepper (Capsicum chinense 'TAM Mild Habanero') was propagated in greenhouses at the HortTREC on 5 Aug. 2016,
10 Feb. 2017, and 3 Aug. 2017. Plants were hand-seeded in 0.52-L black plastic pots (T.O. Plastics., Clearwater, MN) filled with MetroMix 700 media and hand-watered. Fertigation (300 mg. $\mathrm{L}^{-1}$ of $\mathrm{N}$ Peters Professional $20 \mathrm{~N}-$ 8.74P-16.6K) was applied weekly.

\section{Field experiment}

Experimental design. The field portion of this study was performed at the HortTREC field plots in Fall 2016, Spring 2017, and Fall 2017 (Table 1). The experiment was conducted on a 1.2-ha (3-acre) field site where nine 12.2 -m-long $(40-\mathrm{ft}) \times 7.6-\mathrm{m}$-wide $(25$ $\mathrm{ft})$ plots were established with three replicates of each of three treatments: 1) perennial pollinator-attracting companion plants; 2) annual pollinator-attracting companion plants; and 3) no pollinator-attracting companion plants (control plots). Plots were separated on the site from each other by $\approx 61 \mathrm{~m}(200 \mathrm{ft})$ to minimize overlap of the pollinator treatment effects. Thre 12.2-mlong $(40-\mathrm{ft}) \times 1.5$-m-wide $(5-\mathrm{ft})$ crop rows were created within each of the nine plots. Three plots were randomly assigned to either a pollinator-attracting treatment or the control treatment. In each plot, the first $6.1 \mathrm{~m} \mathrm{(20}$ $\mathrm{ft}$ ) of a row was allocated to cucumbers, and the second $6.1 \mathrm{~m}(20 \mathrm{ft})$ was allocated to peppers (Fig. 1).

Field preparation. Plots were established on clay soil with $8.2 \mathrm{pH}$ in Burleson County, TX. A USDA soil survey classifies the soil as Burleson clay, described as "clayey, very deep, nearly level to gently sloping, moderately well drained soils that are slightly alkaline" (USDA, 2014). Irrigation water was provided from an on-site well containing water with $6.9 \mathrm{pH}$ and $1074 \mathrm{mg} \cdot \mathrm{L}^{-1}$ of total dissolved salts. Before each planting, field plots were fertilized with a $17 \mathrm{~N}-7.4 \mathrm{P}-14.1 \mathrm{~K}$ fertilizer (Brazos Best Fortify; Producers Cooperative Assoc., Bryan, TX) at a rate of $0.90 \mathrm{~kg} \mathrm{~N}$ per $93 \mathrm{~m}^{2}\left(2 \mathrm{lb} \mathrm{N}\right.$ per $\left.1000 \mathrm{ft}^{2}\right)$. The areas separating the plots were sown with bermudagrass [Cynodon dactylon (L.) Pers.] and mowed to a height of 10 to $15 \mathrm{~cm}$ (4-6 inches) to minimize pollinator-attracting plants in these intervening spaces. Frequency of pollinator visitation was estimated for each crop species and pollinator-attracting companion species during each cropping cycle as reported by Montoya (2018).

Conventional plots lacking companion plants (control plots). Three plots included crop species without any companion plants that were used as controls. Vegetable crop

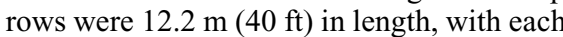

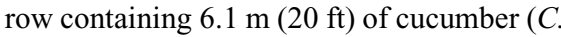
sativus $)$ and $6.1 \mathrm{~m}(20 \mathrm{ft})$ of habanero pepper (C. chinense). The $C$. sativus field row sections were planted in double rows at 30.5-cm (12-inch) spacings, and $C$. chinense field row sections were planted in double rows at $45.7-\mathrm{cm}$ (18-inch) spacings. Spacing between rows was $1.5 \mathrm{~m}(5 \mathrm{ft})$. Plants were planted on black plastic mulch and irrigate with a dual dripline (T-Tape Model 505; Deere and Company, Moline, IL) as needed to maintain turgidity. 
Table 1. Cucumber and habanero planting dates, harvesting periods, maximum/minimum air temperatures, and total rainfall during Fall 2016, Spring 2017, and Fall 2017.

\begin{tabular}{|c|c|c|c|c|c|}
\hline & \multirow[b]{2}{*}{ Planting dates } & \multirow[b]{2}{*}{ Harvesting periods } & \multicolumn{2}{|c|}{ Temperature } & \multirow[b]{2}{*}{ Rainfall (mm) } \\
\hline & & & $\overline{\operatorname{Max}}\left(\left(^{\circ} \mathrm{C}\right)\right.$ & Min. $\left({ }^{\circ} \mathrm{C}\right)$ & \\
\hline \multicolumn{6}{|l|}{ Cucumber } \\
\hline & 20 Sept. 2016 & 2 Nov.-19 Nov. 2016 & 35.6 & 3.3 & 74.42 \\
\hline & 28 Mar. 2017 & 18 May-8 June 2017 & 35.6 & 4.4 & 190.75 \\
\hline & 18 Sept. 2017 & 1 Nov.-22 Nov. 2017 & 35.0 & 8.3 & 112.27 \\
\hline \multicolumn{6}{|l|}{ Habanero } \\
\hline & 23 Sept. 2016 & 7 Nov. -28 Nov. 2016 & 35.6 & 3.9 & 74.17 \\
\hline & 30 Mar. 2017 & 22 May-12 June 2017 & 35.6 & 4.4 & 205.74 \\
\hline
\end{tabular}

Annual species. The annual pollinatorattracting companion planting treatment was planted with three $12.2-\mathrm{m}$-long $(40-\mathrm{ft})$ $\times 1.5$-m-wide $(5-\mathrm{ft})$ rows containing vegetable crop species interplanted with annual companion plants (Fig. 1A). Annual companion plant species rows were interplanted with vegetable crop species at 30.5 - to $45.7-$ $\mathrm{cm}$ (12- to 18-inch) spacings. Vegetable crops were planted as described for the control plots. Spacing between rows was $1.5 \mathrm{~m}(5 \mathrm{ft})$. Plants were planted on black plastic mulch and irrigated with a dual dripline (T-Tape Model 505) as needed to maintain turgidity. Annual plant species were all in flower or beginning flowering when planted to the field and flowered throughout the cropping cycle (Fig. 1A).

Perennial species. The perennial pollinator-attracting companion planting treatments were planted within a 12.2 -m-long $(40-\mathrm{ft}) \times 1.5$-m-wide $(5-\mathrm{ft})$ row containing four perennial pollinator-attracting companion species. Adjacent to this row were two 1.5-m-wide (5-ft) rows in which vegetable crop species were grown as described for the control plots (Fig. 1B and C). Spacing between rows was $1.5 \mathrm{~m}(5 \mathrm{ft})$. Perennial companion plant species field rows were planted at 45.7-cm (18-inch) spacings, alternating three plants across a single row. Perennial companion plants were mulched with $5 \mathrm{~cm}$ ( 2 inches) of composted, shredded pine bark mulch (Ohio Mulch, Columbus, $\mathrm{OH}$ ) and dual dripline-irrigated (T-Tape Model 505) as needed to maintain turgidity. Weed management was conducted initially on a weekly basis by hand-removal until establishment of $P$. nodiflora as a living mulch occurred, at which point weed management was conducted in the perennial companion plant rows only, as needed. Perennial plant species were all in flower or beginning flowering when planted to the field and flowered throughout the cropping cycle, with the exception of Eysenhardtia. texana. $E$. texana began flowering sporadically within a few weeks of planting; then, it did so more consistently during the second growing season.

Cucumber yield. Cucumber yield data were collected during a 3-week harvest period during Fall 2016, Spring 2017, and Fall 2017 (Table 1). Harvest time periods were initiated when a majority of plants contained mature fruit. All cucumbers with a length more than $12.5 \mathrm{~cm}$ were harvested by hand and categorized by grade according to their

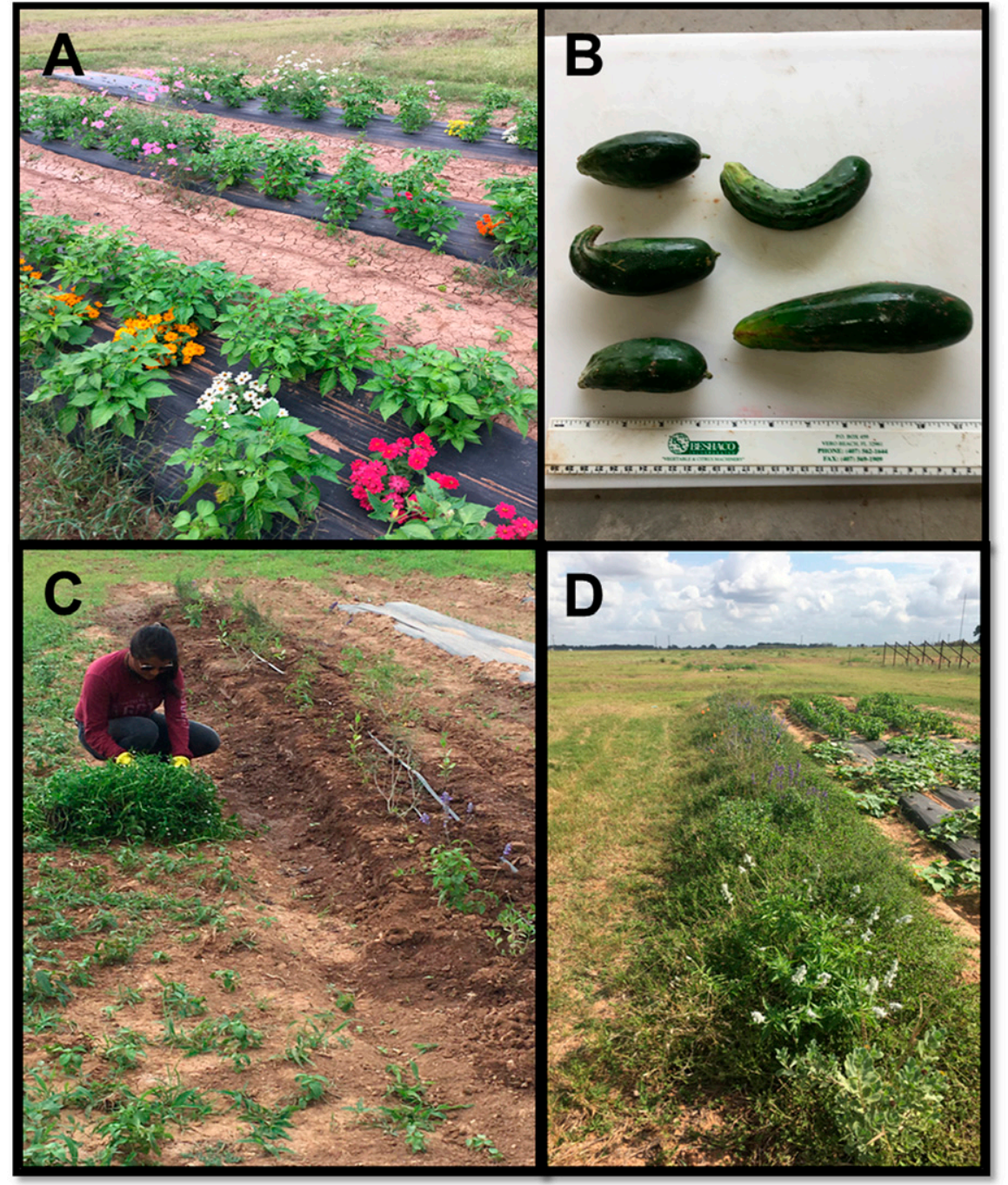

Fig. 1. (A) Annual pollinator-attracting companion plantings, (B) cucumber culls, (C) installation of perennial companion plantings, and (D) perennial companion plantings 1 year after establishment. Note the extensive distance between the pollinator plot in the foreground and the next pollinator plot near the horizon (D).

diameter and length (Fig. 1D) in accordance with the USDA grades for cucumbers (USDA, 2016). Total yield was recorded for each plot, and marketable yield was obtained by summing the fresh weight of cucumbers from all USDA grades; the remaining ones were classified as culls.

Habanero pepper yield. Habanero pepper yield data were collected during a 3-week harvest period during Fall 2016 and Spring 2017 (Table 1). An unexpected early frost prevented a complete harvest of habanero in Fall 2017; therefore, those data were omitted from the analysis. Harvesting time periods were initiated when a majority of plants contained mature fruit. Habaneros were harvested by hand and categorized by grade in accordance with the USDA grades of peppers (USDA, 2016). Total yield and marketable yield for each plot were obtained by summing the fresh weight of habaneros from all USDA grades, with the remaining classified as culls. 
Statistical analysis. Cucumber and habanero yield data were analyzed separately. A randomized complete block design was used with pollinator-attracting treatment and harvests as the main effects. Raw vegetable yield consisted of measuring yields from each plot without making any adjustment for the space used for perennial pollinator attractants. Annual and control treatments represented yields from $83.6 \mathrm{~m}^{2}\left(900 \mathrm{ft}^{2}\right)$, whereas perennial treatments represented yields from $55.7 \mathrm{~m}^{2}\left(600 \mathrm{ft}^{2}\right)$ due to the space required for the perennial pollinator attractants. In our model, it was reasonable to assume that pollinator effects would extend to both sides of a pollinator-attracting row. Therefore, adjusted yield consisted of yields compared for assumed perennial row effects of two adjacent crop rows on each side rather than a single side of the perennial pollinatorattracting companion plants, as tested. These values assumed that one in five rows was used as a perennial pollinator attractant. Raw yields were recorded on a total kilogram basis initially and subsequently converted to a kilogram-per-hectare basis for ease of comparison with small-scale commercial production systems. Higher-order interactions involving blocks and block effects were tested first. When not significant, block effects were omitted from the model. Then, interactions among pollinator-attracting treatments and harvests were tested. If interactions were not significant, then main effects were tested on data pooled across the nonsignificant factor. When effects on yield were found to be statistically significant $(\alpha=0.05)$, the Tukey least-square means tests were performed for means of pollinatorattracting treatments within a harvest (JMP 13; SAS Institute, Cary, NC).

\section{Results and Discussion}

Cucumber yield. Blocking effects were not statistically significant for any of the raw or adjusted yield data $(P \leq 0.05)$. Therefore, Tables 2-4 present the interactions of pollinator-attracting treatments and harvests, omitting blocking effects from the model. Statistical differences $(P \leq 0.05)$ in culls (Fig. 1B) or individual fruit mean weight among treatment groups were not found in Fall 2016, Spring 2017, or Fall 2017 harvests (Table 2). This lack of difference in cull rates or in mean fruit size indicates that there was no impact of pollinator-attracting companion plants on these measures of fruit quality in cucumbers. However, yield data indicated a different story. In Fall 2016, there was a significant difference $(P \leq 0.05)$ among pollinator-attracting companion plant treatments in cucumber raw total and marketable yields (Table 2), and in both raw and adjusted marketable yields on a per-hectare basis (Tables 3 and 4). Raw yield of cucumber was significantly greater with the annual pollinator plant treatment, followed by the control and perennial pollinator plant treatments, respectively (Tables 2 and 3). Adjusted yield, accounting for lost production area in perennial companion plantings for Fall 2016, indicated significant differences $(P$ $<0.05)$ in yield between annual companion plant treatments and the control and perennial companion plant treatments (Table 4). However, no significant difference in adjusted yield was found between the control and the perennial pollinator companion plant treatment in Fall 2016 (Table 4).

In Spring 2017, there was no significant difference $(P<0.05)$ in yield among pollinator-attracting companion plant treatments for cucumber raw total or adjusted yield (Table 2) or among raw or adjusted marketable yields (Tables 3 and 4). In Fall 2017, there was a significant difference $(P<$ $0.05)$ in yield among pollinator-attracting companion plant treatments for cucumber raw total and raw and adjusted marketable yields (Tables 2-4). Annual companion plant treatments had a greater raw yield of cucumbers in Fall 2017 compared with the control and perennial companion plant treatments, which did not differ statistically from each other (Tables 2 and 3). Adjusted marketable yield data indicated significant differences $(P<0.05)$ in yield between annual companion plant treatments and the control and perennial companion plant treatments. However, adjusted marketable yield data for Fall 2017 indicated no significant difference between the control and perennial companion plant treatment (Table 4).

Cucumber yield in Fall 2016, regardless of adjustment, was significantly greater $(P<$ 0.05 ) in the annual companion plant treatment. This is likely attributable to the increased numbers of pollinators visiting cucumber flowers from adjacent flowering annual companion species. The lack of a significant increase in yield with the perennial companion plant treatment may be due to the longer establishment period required for perennial plant species to reach optimum flowering potential. Perennials, other than E. texana, were limitedly flowering at installation (Fig. 1C), but flowering increased substantially as perennial companion plants became more fully established (Fig. 1D). Frequency of pollinator visitation was similar for cucumbers in control plots across harvests and greater in magnitude, but the frequency of visitations across harvests for annual companion treatments were similar; however, visitation of pollinators in cucumber plots increased 3- to 4-fold in the second two harvests compared with the first harvest as perennial companion plantings became more established (Montoya, 2018). Furthermore, during the first harvest, visitations of pollinators were approximately four-times higher on annual companion species, whereas in the final two harvests pollinator visitations were greater on the perennial companion plants (Montoya, 2018). This was consistent across four separate classes of pollinators, honeybees, nonhoneybee species, Diptera, and Lepidoptera (Montoya, 2018).

No significant differences in yield were found among treatments in Spring 2016, regardless of adjustment, which may be attributed to the pollinator abundance already being at a sufficient level across the landscape for adequate pollination without the need for pollinator-attracting companion plants. For instance, Quinn et al. (2017) reported that cucumber yield was largely unaffected by the addition of pollinatorattracting species. However, their data were only obtained during spring harvests, which may explain the similarities with our results in the spring and the differences from our results for cucumber yields in the fall.

In Fall 2017, the cucumber raw yield was again greatest in the annual companion plant treatments. However, the perennial companion plant treatments statistically performed at the same level as the control treatment, regardless of yield adjustment. This suggests that, despite giving up approximately onethird of the production space to perennial companion plants, the increase in yield for the Fall 2017 crop was sufficient to offset the loss of production area. After adjusting for yield, which assumes an effect of two rows on the adjacent sides of the perennial plantings or approximately one-fifth of the production, the perennial and control pollinatorattracting companion plant treatments performed statistically at the same level, but with a greater absolute numerical value. This suggests that it might be possible for perennial plot yields to surpass those in the control plots if a decreased proportion of the production space could be allocated to perennial companion plants without adversely affecting pollinator attraction. Alternatively, the increasing pollinator-attracting ability of perennial plantings as they mature might also increase yields relative to control plantings, as was seen with the annual plantings during fall crops.

Future research for cucumbers will need to determine the maximum row distance at which perennial plantings have a significant impact on yield to further compare perennial planting treatments and control treatments. Increasing the number of rows between perennial companion plantings could allow a greater proportion of the production area to be allocated to crops rather than perennial companion plantings, thus reducing the costs associated with establishing a given acreage with the perennial companion plants. Additional replications of seasonal harvests and establishment of perennial plantings should be examined to determine if the impact on yield of pollinator-attracting companion plants is consistently a seasonal effect, as suggested herein for cucumbers, and to what extent establishment phases of perennial companion plantings can be expected to impact yield. Furthermore, it may be possible to select seasonally superior combinations of annual or perennial companion plantings targeted to coincide more precisely with specific crop flowering cycles, or to more efficiently attract pollinators that are most effective for pollination of specific crops.

Habanero yield. Habanero yields were generally consistent with the results seen for cucumbers in response to 
Table 2. Total yield (Total), marketable yield (Mkt.), cull percentage (Cull), and mean individual fruit weight (Inv.) of pollinator-attracting annual or perennial companion planting treatments on cucumber and habanero in comparison with control plots without companion plants during Fall 2016, Spring 2017, and Fall 2017.

\begin{tabular}{|c|c|c|c|c|c|c|c|c|c|c|c|c|}
\hline \multirow[b]{2}{*}{ Treatment } & \multicolumn{4}{|c|}{ Fall 2016} & \multicolumn{4}{|c|}{ Spring 2017} & \multicolumn{4}{|c|}{ Fall 2017} \\
\hline & Total (kg) & Mkt. (kg) & Cull (\%) & Inv. (g) & Total (kg) & Mkt. (kg) & Cull (\%) & Inv. (g) & Total (kg) & Mkt. (kg) & Cull (\%) & Inv. $(\mathrm{g})$ \\
\hline Perennial & $36.2 \mathrm{c}^{\mathrm{z}}$ & $27.2 \mathrm{c}$ & $24.8 \mathrm{a}$ & $175.9 \mathrm{a}$ & $62.0 \mathrm{a}$ & $47.5 \mathrm{a}$ & $23.4 \mathrm{a}$ & $173.3 \mathrm{a}$ & $51.4 \mathrm{~b}$ & $38.9 \mathrm{~b}$ & $24.4 \mathrm{a}$ & $177.4 \mathrm{a}$ \\
\hline Control & $59.0 \mathrm{~b}$ & $45.9 \mathrm{~b}$ & $22.3 \mathrm{a}$ & $182.4 \mathrm{a}$ & $79.2 \mathrm{a}$ & $58.9 \mathrm{a}$ & $25.7 \mathrm{a}$ & $175.4 \mathrm{a}$ & $61.5 \mathrm{~b}$ & $47.1 \mathrm{~b}$ & $23.4 \mathrm{a}$ & $175.1 \mathrm{a}$ \\
\hline$P$ value & $*$ & $*$ & NS & NS & NS & NS & NS & NS & * & * & NS & NS \\
\hline \multicolumn{13}{|l|}{ Habanero } \\
\hline Perennial & $10.2 \mathrm{c}$ & $9.5 \mathrm{c}$ & $6.2 \mathrm{a}$ & $5.8 \mathrm{a}$ & $17.7 \mathrm{~b}$ & $16.9 \mathrm{~b}$ & $4.2 \mathrm{a}$ & $5.3 \mathrm{a}$ & - & - & - & - \\
\hline$P$ value & * & * & NS & NS & * & * & NS & NS & - & - & - & - \\
\hline
\end{tabular}

${ }^{\mathrm{z}}$ Treatments with the same letters within a species and column are not significantly different (Tukey's highly significantly different test, $\alpha=0.05$ ).

Ns, *Nonsignificant or significant $\mathrm{F}$ test at $P<0.05$, respectively.

Table 3. Effects of pollinator-attracting annual or perennial companion planting treatments on cucumber and habanero pepper total raw yield per plot converted to $\mathrm{kg} / \mathrm{ha}$ in comparison with control plots without companion plants.

\begin{tabular}{|c|c|c|c|}
\hline \multirow[b]{2}{*}{ Treatment } & \multicolumn{3}{|c|}{ Raw yield } \\
\hline & $\begin{array}{c}\text { Fall } 2016 \\
(\mathrm{~kg} / \mathrm{ha})\end{array}$ & $\begin{array}{c}\text { Spring } 2017 \\
(\mathrm{~kg} / \mathrm{ha})\end{array}$ & $\begin{array}{c}\text { Fall } 2017 \\
(\mathrm{~kg} / \mathrm{ha})\end{array}$ \\
\hline \multicolumn{4}{|l|}{ Cucumber } \\
\hline Perennial & $7,793 \mathrm{c}^{\mathrm{z}}$ & $13,351 \mathrm{a}$ & $11,073 \mathrm{~b}$ \\
\hline Annual & $19,278 \mathrm{a}$ & $16,135 \mathrm{a}$ & $19,829 \mathrm{a}$ \\
\hline Control & $12,705 \mathrm{~b}$ & $17,056 \mathrm{a}$ & $13,239 \mathrm{~b}$ \\
\hline$P$ value & $*$ & NS & $*$ \\
\hline \multicolumn{4}{|l|}{ Habanero } \\
\hline Perennial & $2,185 \mathrm{c}$ & $3,810 \mathrm{~b}$ & - \\
\hline Annual & $4,038 \mathrm{a}$ & $5,153 \mathrm{a}$ & - \\
\hline Control & $3,231 \mathrm{~b}$ & $3,687 \mathrm{~b}$ & - \\
\hline$P$ value & $*$ & $*$ & \\
\hline
\end{tabular}

${ }^{\mathrm{z}}$ Treatments with the same letters within a species and column are not significantly different (Tukey's highly significantly different test, $\alpha=0.05$ ).

Ns, *Nonsignificant or significant $\mathrm{F}$ test at $P<0.05$, respectively.

Table 4. Effects of pollinator-attracting annual or perennial companion planting treatments on cucumber and habanero adjusted total yield per plot to $\mathrm{kg} \cdot \mathrm{ha}^{-1}$ in comparison with control plots without companion plants.

\begin{tabular}{|c|c|c|c|}
\hline \multirow[b]{2}{*}{ Treatment } & \multicolumn{3}{|c|}{ Yield } \\
\hline & $\begin{array}{l}\text { Fall } 2016 \\
\left(\mathrm{~kg} \cdot \mathrm{ha}^{-1}\right)\end{array}$ & $\begin{array}{c}\text { Spring } 2017 \\
\left(\mathrm{~kg} \cdot \mathrm{ha}^{-1}\right)\end{array}$ & $\begin{array}{l}\text { Fall } 2017 \\
\left(\mathrm{~kg} \cdot \mathrm{ha}^{-1}\right)\end{array}$ \\
\hline \multicolumn{4}{|l|}{ Cucumber } \\
\hline Perennial & $8,654 b^{z}$ & $14,746 \mathrm{a}$ & $12,303 \mathrm{~b}$ \\
\hline Annual & $19,278 \mathrm{a}$ & $16,135 \mathrm{a}$ & $19,829 \mathrm{a}$ \\
\hline Control & $12,705 \mathrm{~b}$ & $17,056 \mathrm{a}$ & $13,239 \mathrm{~b}$ \\
\hline$P$ value & $*$ & NS & $*$ \\
\hline \multicolumn{4}{|l|}{ Habanero } \\
\hline Perennial & $2,427 \mathrm{~b}$ & $4,230 \mathrm{~b}$ & - \\
\hline Annual & $4,038 \mathrm{a}$ & $5,153 \mathrm{a}$ & - \\
\hline Control & $3,231 \mathrm{~b}$ & $3,687 \mathrm{~b}$ & - \\
\hline$P$ value & $*$ & $*$ & - \\
\hline
\end{tabular}

${ }^{\mathrm{z}}$ Treatments with the same letters within a species and column are not significantly different (Tukey's highly significantly different test, $\alpha=0.05$ ).

Ns, *Nonsignificant or significant $\mathrm{F}$ test at $P<0.05$, respectively.

pollinator-attracting companion plants (Tables 2-4). As with cucumber crops, yield measures were significantly affected $(P<$ $0.05)$, but no effects attributable to pollinator-attracting companion plants were seen for the fruit quality measures of cull percentages or mean fruit mass (Table 2). In Fall 2016, there was a significant difference $(P<0.05)$ in yield among pollinatorattracting companion plant treatments in habanero raw total yield (Table 2) and in raw and adjusted marketable yield (Tables 3 and 4). Similarly, in Fall 2016, a significant difference in raw yield was present between annual companion planting treatments and the control and perennial treatments, with the annual plantings treatment ranking highest, followed by the control and perennial treatments, respectively. When adjustments to yield for space occupied by perennial plantings were factored into the analysis, no differences were found among perennial and control treatments for the habanero crop in Fall 2016 (Table 4).

In Spring 2017, there was a significant difference $(P<0.05)$ in yield among pollinator-attracting companion plant treatments in habanero raw total yield, as well as raw and adjusted marketable yield (Tables 2-4). Annual companion plant treatment raw yields were greater than the control and perennial companion plant treatments. However, no significant difference in yield was found between the raw total yield or raw or adjusted marketable yields between the control and the perennial pollinator companion plant treatments (Tables 2-4). This suggests that increased yields due to inclusion of perennial plants were sufficient to offset the allocation of approximately one-third of the space to perennial plants (Tables 2 and 3 ).

Adjusted yield data for Spring 2017 indicated that the perennial plantings were intermediate numerically between the annual plot yields and control plots and did not differ statistically from the controls (Table 4). Habanero yields suggest that the pollinatorattracting companion plant species impact yields within a shorter time duration when compared with our results with cucumbers. In addition, it appears that, in the spring, pollinator-attracting companion plant species can influence the habanero, but not the cucumber, yield. We suggest that additional replications of seasonal harvests should be performed to confirm the pollinator-attracting companion plant species' impact on seasonal habanero yield.

\section{Conclusions}

Annual companion plantings were more effective at enhancing the yield of adjacent crops species than perennial companion species under the tested conditions and timeframes. Similar responses were observed in both cucumber and habanero crops in response to pollinator-attracting companion plantings in a general sense. Fruit quality measures in terms of cull percentages and mean fruit masses for cucumber and habanero pepper were unaffected by the presence of pollinator-attracting companion plantings. The lack of differences in several yield measures between perennial companion plant plots and control plots, despite the allocation of one in three or one in five rows to the perennial plantings, suggests that there is 
potential for yields in perennial companion plots to surpass those of control plots if the effective distance between rows occupied by perennial plantings is increased. The apparent seasonality of responses to pollinatorattracting companion plantings suggests that it may be feasible to improve responses even further by maximizing the fit of annual and perennial companion plant bloom cycles with that of targeted crops. Our results also suggest a time lag for perennial plants to reach maximum effectiveness (Fig. 1C vs. Fig. 1D).

Benefits associated with the additional pollination and ecosystem services resulting from the year-round presence of the perennial plantings on other crops during the year or long-term pollinator populations were not determined in this study, but they also represent potential tangible benefits of perennial companion plantings. The goal of this study was to investigate from a horticulture perspective (not one focused on entomology) whether crop yield can be reliably increased by the addition of pollinator-attracting crops (Haaland et al., 2011). Similar cross-disciplinary approaches that bring plant and pollinator scientists together may be needed to accurately investigate how plants that attract pollinators can increase the yield of vegetable crops.

\section{Literature Cited}

Arnold, M.A. 2008. Landscape plants for Texas and environs. 3rd ed. Stipes Publ. L.L.C., Champaign, IL.

Barbir, J., F.R. Badenes-Pérez, C. FernándezQuintanilla, and J. Dorado. 2015. Can floral field margins improve pollination and seed production in coriander Coriandrum sativum L. (Apiaceae)? Agr. For. Entomol. 17:302-308.

Calderone, N.W. 2012. Insect pollinated crops, insect pollinators and US agriculture: Trend analysis of aggregate data for the period 1992 2009. PLoS One 7(5):e37235.

Carreck, N. and I. Williams. 2002. Food for insect pollinators on farmland: Insect visits to flowers of annual seed mixtures. J. Insect Conserv. 6:13-23.

Cauich, O., J.J.G. Quezada Euán, V.M. Ramírez, G.R. Valdovinos-Nuñex, and H. Moo-Valle. 2006. Pollination of habanero pepper (Capsicum chinense) and production in enclosures using the stingless bee Nannotrigona perilampoides. J. Apic. Res. 45(3):125-130.

Cotner, S. 1998. McMillen's Texas gardening: Vegetables. Gulf Publ. Co., Houston, TX.

Food and Drug Administration. 2016. Bell and chile peppers. Food and Drug Administration, Western Institute for Food Safety and Security.

Gallai, N., J.M. Salles, J. Settele, and B.E. Vaissiere. 2009. Economic valuation of the vulnerability of world agriculture confronted with pollinator decline. Ecol. Econ. 68:810-821.

Gilman, E.F. 1999. Borrichia frutescences sea oxeye. FPS69. Univ. Florida Institute of Food and Agric. Sci. Extension, Gainesville, FL.

Haaland, C., R.E. Naisbit, and L. Bersier. 2011. Sown wildflower strips for insect conservation: A review. Insect Conserv. Divers. 4:60-80.

Julier, H.E. and T.H. Roulston. 2009. Wild bee abundance and pollination service in cultivated pumpkins: Farm management, nesting behavior and landscape effects. J. Econ. Entomol. 102(2):563-573.

Kevan, P.G. and T.P. Phillips. 2001. The economic impacts of pollinator declines: An approach to assessing the consequences. Conserv. Ecol. $5(1): 8$

Masabni, J. 2010. Easy gardening: Cucumbers. EHT-033. Texas A\&M AgriLife Ext., College Station, TX.

Montoya, J.E., Jr. 2018. Evaluating perennial and annual companion plantings for pollinator enhancement of yield in small-scale vegetable production. PhD Diss., Texas A\&M Univ., College Station, TX.
Morandin, L.A. and C. Kremen. 2013. Hedgerow restoration promotes pollinator populations and exports native bees to adjacent fields. Ecol. Appl. 23:829-839.

Potts, S.G., B. Vulliamy, A. Dafni, G. Ne'eman, and P. Willmer. 2003. Linking bees and flowers: How do floral communities structure pollinator communities? Ecology 84:26282642.

Quinn, N.F., D.C. Brainard, and Z. Szendrei. 2017. Floral strips attract beneficial insects but do not enhance yield in cucumber fields. J. Econ. Entomol. 110(2):517-524.

Redhage, D. and M. McDermott. 2015. The Kerr Center guide to: Native plants for native pollinators in Oklahoma. Kerr Center for Sustainable Agriculture, Poteau, OK.

Texas Superstar Program. 2016. Texas Superstar® strong and stunning plants for Texans. Texas Dept. Agric., Texas A\&M AgriLife Ext., Texas A\&M AgriLife Res., College Station, TX.

Thom, M.D., C.A. Eberle, F. Forcella, R. Gesch, S. Weyers, and J.G. Lundgren. 2016. Nectar production in oilseeds: Food for pollinators in an agricultural landscape. Crop Sci. 56:727739.

University of Georgia Honey Bee Program. 2019. Crop pollination requirements. Univ. Georgia, Athens, GA. 10 Oct. 2019. <https://bees.caes. uga.edu/bees-beekeeping-pollination/pollination/ pollination-crop-pollination-requirements.html $>$.

U.S. Department of Agriculture. 2014. Soil Survey of Burleson County, Texas. U.S. Dept. Agr., Washington, D.C.

U.S. Department of Agriculture. 2016. United States Standards for Grading of Cucumbers. U.S. Dept. Agr., Washington, D.C.

Williams, G.R., D.R. Tarpy, D. vanEngelsdorp, M. Chauzat, D.L. Cox-Foster, K.S. Delaplane, P. Neumann, J.S. Pettis, R.E. Rogers, and D. Shutler. 2010. Colony collapse disorder in context. BioEssays 32:845-846.

Winfree, R., I. Bartomeus, and D.P. Cariveau. 2011. Native pollinators in anthropogenic habitats. Annu. Rev. Ecol. Evol. Syst. 42:1-22. 